\title{
Floral Biology and in vitro Germination of Nasturtium Pollen Grains Grown With Poultry Litter
}

\author{
G. T. Zanetti ${ }^{1}$, L. M. C. Davide ${ }^{1}$, M. do C. Vieira ${ }^{1}$, N. A. H. Zárate ${ }^{1}$, A. M. T. Alovisi ${ }^{1}$, O. B. da Silva ${ }^{1}$ \\ \& T. de O. Carnevali ${ }^{1}$ \\ ${ }^{1}$ Universidade Federal da Grande Dourados, Dourados, Mato Grosso do Sul, Brazil \\ Correspondence: G. T. Zanetti, Universidade Federal da Grande Dourados, Dourados, Mato Grosso do Sul, \\ Brazil. Tel: 55-679-9696-7246. E-mail: gessicabiotec@gmail.com
}

$\begin{array}{lc}\text { Received: February 8, } 2019 & \text { Accepted: April 1, } 2019 \quad \text { Online Published: May 31, } 2019 \\ \text { doi:10.5539/jas.v11n7p160 } & \text { URL: https://doi.org/10.5539/jas.v11n7p160 }\end{array}$

\begin{abstract}
The plant Tropaeolum majus, popularly known as nasturtium, presents food, ornamental and medicinal importance. Studies on floral and carpometric characteristics generate basic knowledge for areas of science such as botany, genetics and plant breeding. This work has the objectives of analyzing the effect of combinations of doses of poultry litter on floral structures and the in vitro germination of T. majus pollen grains. From the experimental matrix Plan Puebla III were defined 9 combinations of poultry litter doses incorporated and covered. The design of the experiments was entirely random, varying the replicates number. The number of stamens, petals, sepals and carpels was verified per floral bud in each treatment. The in vitro germination rate of pollen grains was estimated in 5 culture media and 2 germination times, from flower buds randomly collected in the experiment. The overall mean of stamens, sepals, petals and carpels per floral bud was $8.23 ; 5 ; 5$ and 3 , respectively. The combinations of poultry litter doses influenced only the number of stamens. The in vitro germination rate of $T$. majus pollen grains varied in the culture media. There was no association between the combinations of poultry litter doses and the in vitro germination rate of pollen grains.
\end{abstract}

Keywords: Tropaeolum majus, organic fertilization, plan puebla III, phenotypic plasticity, stamens

\section{Introduction}

The plant Tropaeolum majus L. is popularly known as nasturtium, "chagas", blood flower, or mexico watercress. This specie belongs to the Tropaeolaceae family, and it can be found mainly in Colombia, Brazil and Peru as a primitive diverse plant (Pintão, 1995).

T. majus has been used in popular medicine for presenting antiviral, antibacterial, antifungal and antitumor properties (Pintão, 1995). Its leaves can be use for the treatment of diseases related to cardiovascular disorders, urinary tract infections, asthma and constipation (Ferro, 2006). The flowers are considered edible, used for human consumption in the preparation of many dishes (Botrel, 2016). According to Husti et al. (2013), T. majus is an excellent source of minerals and antioxidants, flowers taste nice and spicy.

The flowers morphology, as angiosperms, is utilized as a source of taxonomic characteristics to identify families, genus and species. Studies that envolve the sexual reproduction of plants are based on their floral structures and polinization according to Vieira and Fonseca (2014). The knowledge of the floral and carpometric characteristics is important for the selection of the parents to be used in breeding programs (Clark, 2008). The pollen grain viabilities and the germinative capacity allow greater reproductive success in the stages of hybridization (Danner et al., 2011).

The most widely used method for evaluating the viability of pollen grains in breeding programs is in vitro germination (Franzon et al., 2006). An external factor capable of interfering with the germination of pollen grains is soil fertility (Stanley \& Linskens, 1974). In order to increase potassium, phosphorus and sulfur contents in the soil, the poultry litter is used in plant crops, providing higher productivity (Finatto et al., 2013). In T. majus, cultivation with poultry litter induced increased production of fresh flower masses and fruit droughts (Sangalli, 2004).

According to Pigliucci (2001), a genotype can produce different phenotypes in response to diverse environmental conditions. This is a mechanism that generates phenotypic variability and points out its importance in the adaptive 
and evolutionary processes of plants (Cardoso \& Lomônaco, 2003). Considering the potential of the specie and the importance of floral biology and in vitro germination studies, the objective of this study was to evaluate the effect of poultry litter doses on floral structures of T. majus. In addition, to verify the best culture medium and germination time of the in vitro germination of T. majus pollen grains. And, to estimate the association between the combinations of poultry litter doses and the in vitro germination of pollen grains of T. majus.

\section{Methods}

\subsection{Experimental Design}

The experiment was carried out in the Medicinal Plants Garden and in the Genetics and Plant Breeding Laboratory of the Faculdade de Ciências Agrárias, Universidade Federal da Grande Dourados, in Dourados-MS, Brazil (Figure 1). The garden is situated on the latitude of $22^{\circ} 11^{\prime} 44^{\prime \prime} \mathrm{S}$, longitude of $54^{\circ} 56^{\prime} 07^{\prime \prime} \mathrm{W}$ and altitude of $452 \mathrm{~m}$.

The climate of Dourados, according to classification of Köppen is Cwa, with average annual temperatures and precipitations varying from $20^{\circ} \mathrm{C}$ to $24^{\circ} \mathrm{C}$ and from $1250 \mathrm{~mm}$ to $1500 \mathrm{~mm}$. The soil in the cultivation area is a very clayey dystrophic red oxisol, containing $32 \mathrm{~g} \mathrm{dm}^{-3}$ of organic matter; $38 \mathrm{mg} \mathrm{dm}^{-3}$ of P; 8.2; 51.3 and $17.0 \mathrm{mmolc}$ $\mathrm{dm}^{-3}$ of $\mathrm{K}, \mathrm{Ca}$ and $\mathrm{Mg}$, respectively.

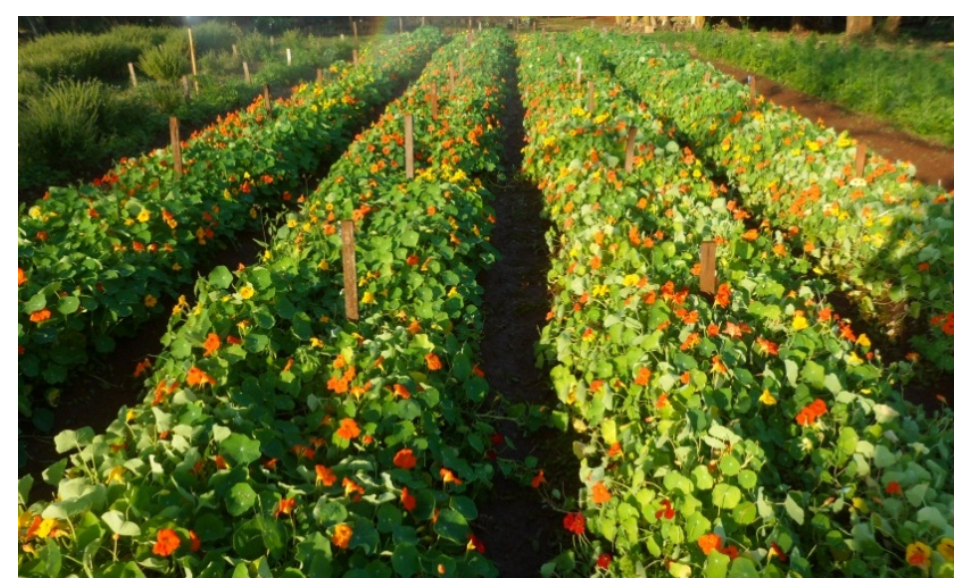

Figure 1. T. majus cultivation with the usage of the poultry litter (Photo by O. B. da Silva)

The seeds of T. majus 345 (Isla Pro ${ }^{\circledR}$ ) were cultivated in April of 2016 using the substrate Tropstrato ${ }^{\circ}$, recommended for hot climate. The seedlings were kept in trays measuring up to seven centimeters in trays of 128 cells in a protected environment with Sombrite ${ }^{\circledR}(50 \%)$.

The day before the transplanting of the seedlings, the poultry litter was added to the soil in order to raise the levels of nitrogen, potassium, phosphorus and sulfur. The poultry litter used had the following composition: organic C: $396.00 \mathrm{~g} \mathrm{~kg}^{-1}$; P: $6.17 \mathrm{~g} \mathrm{~kg}^{-1}$; K: $2.00 \mathrm{~g} \mathrm{~kg}^{-1}$; N: $11.03 \mathrm{~g} \mathrm{~kg}^{-1}$; Ca: $14.85 \mathrm{~g} \mathrm{~kg}^{-1} ; \mathrm{Mg}: 4.5 \mathrm{~g} \mathrm{~kg}^{-1} ; 8.23 \mathrm{~g} \mathrm{~kg}$; $\mathrm{C} / \mathrm{N}$ : $35.90 \mathrm{~g} \mathrm{~kg}^{-1}$.

The treatments were defined using the Plan Puebla III experimental matrix, generating nine combinations of incorporated and in coverage poultry litter doses (Table 1). The experimental plots had 16 plants in a usable area of $2 \mathrm{~m}^{2}$, with spacing of $25 \mathrm{~cm}$ between plants and $50 \mathrm{~cm}$ between rows. 
Table 1. Composition of treatments with poultry litter for T. majus cultivation

\begin{tabular}{lll}
\hline \multirow{2}{*}{ Treatments } & \multicolumn{2}{c}{ Poultry litter } \\
\cline { 2 - 3 } & Incorporated $\left(\mathrm{t} \mathrm{ha}^{-1}\right)$ & Coverage $\left(\mathrm{t} \mathrm{ha}^{-1}\right)$ \\
\hline 1 & 6 & 6 \\
2 & 14 & 6 \\
3 & 6 & 14 \\
4 & 14 & 14 \\
5 & 10 & 10 \\
6 & 1 & 6 \\
7 & 19 & 14 \\
8 & 6 & 1 \\
9 & 14 & 19 \\
\hline
\end{tabular}

\subsection{Influences of the Poultry Litter Doses in the Floral Structure of T. majus}

\subsubsection{Sampling Procedures}

In October 2016, in the morning, flower buds were collected randomly from each treatment in their early blooming stage (Figure 2). The number of stamens, carpels, petals and sepals were evaluated in the laboratory. Carpels were evaluated by visualizing the stigma divisions in gynoecium, as described by Silva et al. (2011). The design was completely randomized, with 10 replicates.

\subsubsection{Statistical Analysis}

Data was submitted to analysis of variance and comparison of means. The Tukey's test was used at 5\% of probability. Afterwards, the response surface was obtained by adjusting the means to the linear and quadratic models. The statistical tests were performed in the Genes Program, SAEG and SigmaPlot.

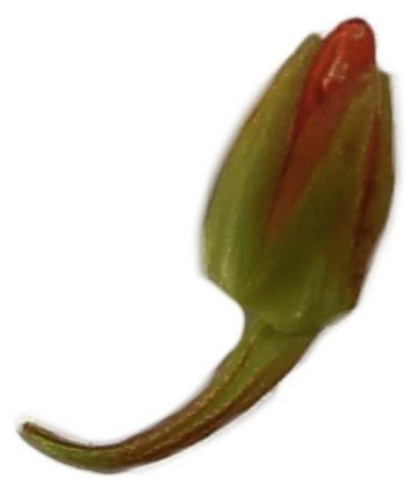

Figure 2. T. majus floral bud in the stadium "balloon" (Photo by G. T. Zanetti)

\subsection{In Vitro Germination of Pollen Grains in Different Culture Media and Germination Times}

\subsubsection{Sampling Procedures}

The collection of floral buds of T. majus was performed in a random way in the experiment, regardless of the treatments. In the laboratory, pollen grains of two anthers per floral bud were removed with the aid of a magnifying glass and forceps. Then, they were placed in Petri dishes, containing $20 \mathrm{~mL}$ of culture medium and maintained on the laboratory bench.

\subsubsection{Measures}

The analysis of in vitro germination rates of T. majus pollen grains was performed in a completely randomized design, in a $5 \times 2$ factorial scheme (culture media $\times$ germination times), with 3 replicates. The germinated grains, only those that presented a pollen tube of length equal to or greater than the diameter of the pollen itself (Figure 3) were counted, according to Figueiredo et al. (2013). 


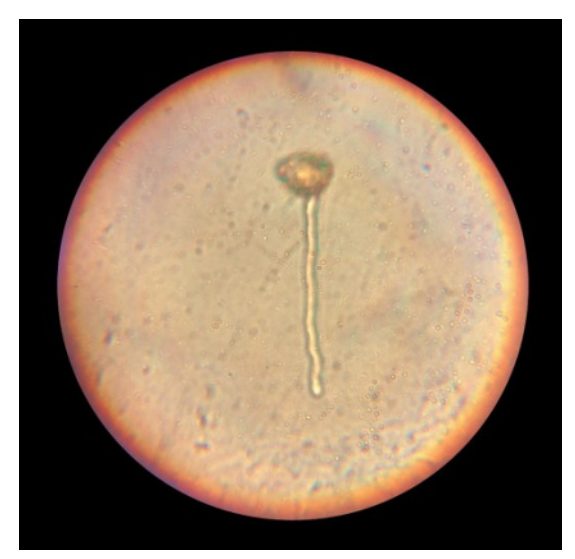

Figure 3. T. majus grain of polen germinating (Photo by G. T. Zanetti)

The counting of germinated pollen grains was performed under an optical microscope of 10X magnification, considering four fields of vision of the Neubauer chamber as a repetition. The in vitro germination rate was obtained from the division of the number of pollen grains germinated by the total number of pollen from the replicate. The culture media's composition used was described in Table 2. The pollen grains germination time were defined according to Figueiredo et al. (2013) in 3 and 4 hours after distribution in Petri dishes.

Table 2. Composition of the culture medium used to evaluate the in vitro germination of $T$. majus pollen grains

\begin{tabular}{lllll}
\hline Culture Medium & Sucrose (\%) & $\mathrm{H}_{3} \mathrm{BO}_{3}(\%)$ & $\mathrm{CaNO}_{3}(\%)$ & Agar (\%) \\
\hline CM1 & 10 & 0.03 & 0.15 & - \\
$\mathrm{CM} 2$ & 17 & 0.01 & 0.03 & 0.7 \\
$\mathrm{CM} 3$ & 15 & 0.03 & - & 0.6 \\
$\mathrm{CM} 4$ & 15 & 0.02 & 0.03 & 0.6 \\
CM5 & 25 & - & - & 0.8 \\
\hline
\end{tabular}

\subsubsection{Statistical Analysis}

The data was transformed to square root of $\mathrm{x}+1$ and submitted to variance analysis. Then, the means were compared by the Tukey test at $5 \%$ probability.

\subsection{Association Between Combinations of Poultry Litter Doses and in Vitro Germination of T. majus}

\subsubsection{Measures}

In vitro germination was estimated using pollen grains of T. majus flower buds collected in each treatment described in Table 1. In the laboratory, pollen removal procedures were carried out in the anthers and evaluation of in vitro germination rate according to sub-item 2.3.2.

The analyzes occurred after 4 hours of pollen distribution on the plates containing culture medium 4 (15\% sucrose, $0.02 \%$ boric acid, $0.03 \%$ calcium nitrate and $0.6 \%$ agar). The design was completely randomized with 3 replicates.

\subsubsection{Statistical Analysis}

Data was submitted to analysis of variance. The surface response was estimated based on linear and quadratic model adjustments. The Genes Programs, SAEG and SigmaPlot were used.

\section{Results}

\subsection{The Influence of Poultry Litter Doses in T. majus Floral Structure}

The analysis of variance only revealed statistical difference for the characteristic number of stamens in T. majus (Table 3). The overall mean number of stamens in the experiment was 8.23, corroborating Silva et al. (2011) who observed 8 stamens with different sizes in the floral buds of T. majus, being 4 larger, 3 medium and 1 smaller. 
Table 3. Summary of variance analysis for number of T. majus stamens

\begin{tabular}{lll}
\hline SV & DF & MQ \\
\hline Treatments & 8 & $4.70^{* *}$ \\
Residue & 81 & 0.6 \\
Total & 89 & 0.97 \\
\hline CV $(\%)$ & 9.4 & \\
Overall mean & 8.23 & \\
\hline
\end{tabular}

Note. SV: sources of variation, FD: degree of freedom, MQ: medium squares, ** Significant at $1 \%$ probability, by F test, ns: non-significant.

The flowers of plants cultivated with $6 \mathrm{t} \mathrm{ha}^{-1}$ of poultry litter incorporated and $14 \mathrm{t} \mathrm{ha}^{-1}$ in coverage presented greater stamens, 10 per floral bud (Table 4). In the remaining treatments the mean stamens ranged from 7.8 to 8.4 .

Table 4. Average number of stamens in T. majus floral buds with poultry litter

\begin{tabular}{llll}
\hline Treatments & Incorporated $\left(\mathrm{t} \mathrm{ha}^{-1}\right)$ & Coverage $\left(\mathrm{t} \mathrm{ha}^{-1}\right)$ & Average \\
\hline 1 & 6 & 6 & $7.8 \mathrm{~b}$ \\
2 & 14 & 6 & $8.4 \mathrm{~b}$ \\
3 & 6 & 14 & $10.0 \mathrm{a}$ \\
4 & 14 & 14 & $8.0 \mathrm{~b}$ \\
5 & 10 & 10 & $8.1 \mathrm{~b}$ \\
6 & 1 & 6 & $8.0 \mathrm{~b}$ \\
7 & 19 & 14 & $8.0 \mathrm{~b}$ \\
8 & 6 & 1 & $7.8 \mathrm{~b}$ \\
9 & 14 & 19 & $8.0 \mathrm{~b}$ \\
\hline
\end{tabular}

Note. Averages followed by the same letters in column do not differ statistically from each other by the Tukey test at $5 \%$ probability.

Values close to 10 stamens per floral bud of T. majus could also be obtained using the combination of $1.0 \mathrm{tha}^{-1}$ of incorporated poultry litter and $19.0 \mathrm{t} \mathrm{ha}^{-1}$ in coverage (Figure 4). This data suggests that the benefits provided by poultry litter doses in conjunction with environmental factors may be associated with changes in the number of $T$. majus stamens.

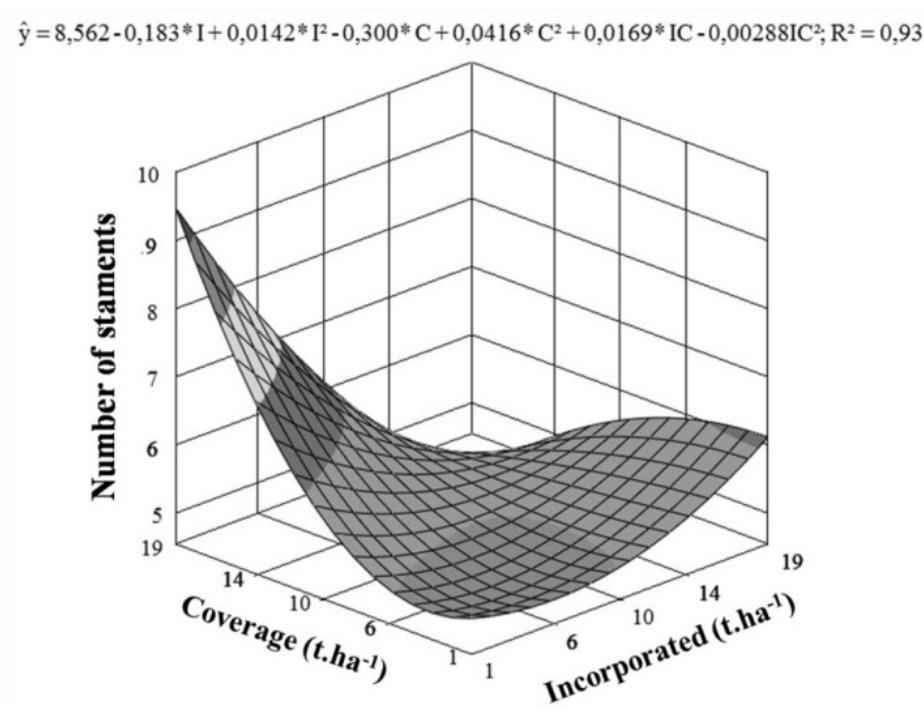

Figure 4. Surface response of the number of T. majus stamens according to poultry litter doses incorporated and in coverage 


\subsection{In Vitro Germination of Pollen Grains in Different Culture Media and Germination Times}

No significant differences were observed in the interaction between the germination times and culture media. Likewise, no significant differences were observed for the germination times. However, the culture media promoted distinct in vitro germination rates of T. majus pollen grains. The overall in vitro germination mean of pollen grains from the experiment was $27.94 \%$ (Table 5). The absence of in vitro germination tests in T. majus makes it impossible to relate these results to other studies.

Table 5. Analysis of variance for the in vitro germination of $T$. majus pollen grains evaluated at different germination times and culture media

\begin{tabular}{lll}
\hline SV & DF & MQ \\
\hline Culture Media (CM) & 4 & $26.25^{* *}$ \\
Germination Times (GM) & 1 & $8.99^{\text {ns }}$ \\
CM $\times$ GM & 4 & $3.67^{\text {ns }}$ \\
Residue & 20 & 4.42 \\
Total & 29 & 7.49 \\
\hline CV (\%) & 16.00 & \\
Overall mean (\%) & 27.94 & \\
\hline
\end{tabular}

Note. SV: sources of variation, DF: degree of freedom, MQ: medium squares, ${ }^{* *}$ Significant at $1 \%$ probability, by F test. Ns: non-significant, CM: culture media, GM: germination times.

Culture medium 5, composed only of sucrose and agar, presented the lowest average in vitro germination rate of pollen grains (Table 6).

Table 6. Average in vitro germination rate of T. majus pollen grains evaluated in different culture media

\begin{tabular}{ll}
\hline Culture Media & Average \\
\hline M1 & $32.83 \mathrm{a}$ \\
M2 & $26.03 \mathrm{a}$ \\
M3 & $37.07 \mathrm{a}$ \\
M4 & $40.03 \mathrm{a}$ \\
M5 & $0.16 \mathrm{~b}$
\end{tabular}

Note. Averages followed by the same letters do not differ statistically from each other by the Tukey test at $5 \%$ probability.

\subsection{Association Between Combinations of Poultry Litter Doses and in Vitro Germination of T. majus}

In vitro germination rates of $T$. majus pollen grains were not influenced by the combinations of poultry litter doses, the overall mean was $28.21 \%$ (Table 7).

Table 7. Analysis of variance for the in vitro germination of T. majus pollen grains evaluated in treatments with incorporated poultry litter and in coverage

\begin{tabular}{lll}
\hline SV & DF & MQ \\
\hline Treatments & 8 & $212.00^{\text {ns }}$ \\
Residue & 18 & 225.62 \\
Total & 26 & 221.43 \\
\hline CV $(\%)$ & 53.24 & \\
Overall mean (\%) & 28.21 & \\
\hline
\end{tabular}

Note. SV: sources of variation, DL: degree of freedom, MQ: medium squares, ** Significant at $1 \%$ probability, by F test. ns: non-significant. 
The response surface allowed to observe the behavior of $T$. majus in vitro germination rates in various combinations of poultry litter doses. The highest in vitro germination rate of pollen grains estimated on the response surface (\%) was obtained on combination of $1.0 \mathrm{t} \mathrm{ha}^{-1}$ of incorporated poultry litter and $19.0 \mathrm{tha} \mathrm{h}^{-1}$ in coverage. However, high amounts of poultry litter incorporated and small in coverage can lead to low rates of in vitro germination. The highest estimated values of the stamen numbers and in vitro germination were displayed in the ascent region of the response surfaces according to the same combinations of poultry litter doses (Figure 5).

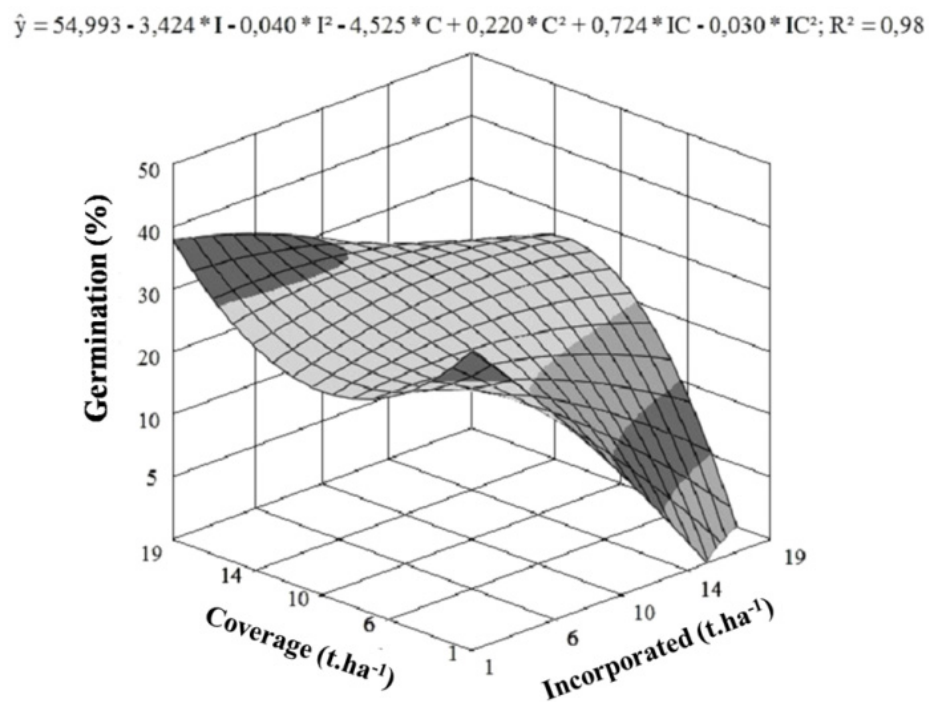

Figure 5. Response surface of in vitro germination of T. majus pollen grains according to poultry litter doses incorporated and in coverage

\section{Discussion}

\subsection{The Influence of Poultry Litter Doses in T. majus Floral Structure}

The increase in the number of stamens per flower possibly relates to the release of nutrients from the poultry litter on the soil and to the plant. In addition, it may favor the reproduction process, since, according to Vieira and Fonseca (2014), the morphology and biology of flowers are directly related to their mechanisms of pollination and reproduction.

Carpels, petals and sepals were not influenced by treatments. Each floral bud had 3 carpels, 5 petals and 5 sepals. These results are in agreement with Silva et al. (2011), which verified the presence of corolla and chalice pentamers and gynoceum with stigma divided into 3 parts, which corresponds to the existence of 3 carpels.

The response surface of the number of T. majus stamens according to poultry litter doses exhibited two regions of ancestry (Figure 4). The combination of poultry litter doses of less than $10 \mathrm{tha}^{-1}$ incorporated and above $10 \mathrm{tha}^{-1}$ in coverage result in region containing the highest values.

According to Majetic et al. (2017), floral structures may be impacted by abiotic factors due to phenotypic plasticity. Plastic responses are functionally adaptive and include unavoidable effects of environmental limits on plant growth and physiology, favoring the organism's success in the environment that causes them (Sultan, 2000). Therefore, this phenomenon reports the possible impact of poultry litter doses on T. majus morphology.

\subsection{In Vitro Germination of Pollen Grains in Different Culture Media and Germination Times}

It is possible to compare the average rate of in vitro germination obtained with those observed in other species, reported in the literature, as in Eriobotrya japonica (46.6\%) by Nogueira et al. (2015) and tetraploid banana hybrids (12.79\%), by Soares et al. (2016).

Differences in the in vitro germination process of Glycine max L. pollen grains may occur as a result of the complex interaction between morphology and physiology of pollen grains and what composes the medium (Gwata et al., 2003). Thus, different species may present varying in vitro germination rates of pollen grains.

The low percentage of germination obtained in this medium can be explained by the fact that the absence of boric acid and calcium nitrate hinder the development of the pollen tube in vitro (Chagas et al., 2010). 
The boron importance in culture media for evaluating the in vitro germination of pollen grains has been proven in different species such as Physalis spp. (Silva et al., 2017), Rubus spp. (Figueiredo et al., 2013), Pyrus calleryana and Pyrus betulaefolia (Chagas et al., 2010).

Boron maximizes in vitro germination and, according to Pfahler (1968), is associated with the formation of sugar borate complexes, which allows the increase of sugar absorption, translocation and metabolism. It also promotes increased oxygen uptake and synthesis of pectin materials into the wall of pollen tubes.

Silva et al. (2017) verified that the addition of calcium nitrate to the culture medium favored in vitro increase in germination of the pollen grains by $30 \%$ for Physalis angulata L. On the other hand, calcium nitrate did not favor the germination of pollen grains in species such as Cydonia oblonga (Zambon et al., 2014), Rubus spp. (Figueiredo et al., 2013) and Pyrus spp. (Chagas et al., 2010). Pfahler (1968) observed that calcium is apparently associated with binding in the membrane regions of the pollen tube, increasing the stiffness and stability of the wall, resulting in reduced rupture.

\subsection{Association Between Combinations of Poultry Litter Doses and in Vitro Germination of T. majus}

The use of poultry manure, poultry litter, organic compounds and other types of sources of organic matter in the production of vegetables are practices increasingly used by producers. According to Lemes et al. (2014), the poultry litter has efficiency in increasing the productivity of oleraceous and has the potential to be used as nitrogen fertilization.

Although the response surface (Figure 5) has shown that the highest in vitro germination rate of pollen grains occurred in the combination of $1.0 \mathrm{t} \mathrm{ha}^{-1}$ of incorporated poultry litter and $19.0 \mathrm{t} \mathrm{ha}^{-1}$ in the coverage, large amounts of poultry litter incorporated and small in coverage can lead to low rates of in vitro germination.

This fact may be associated to the absence of nutrient balances, according to Noce et al. (2014), in many cases, reveals the need for addition of supplements to organic fertilization as another source of nutrients that are not present in adequate amounts. According to Ávila (2007), the use of poultry litter as an organic fertilizer should be according to the principle of nutrient balance, matching the soil fertility characteristics, crop requirements and nutrient content of the product.

\section{Conclusions}

The combination of $6 \mathrm{t} \mathrm{ha}^{-1}$ incorporated poultry litter and $14 \mathrm{t} \mathrm{ha}^{-1}$ of coverage may have provided T. majus floral buds with 10 stamens, a larger amount than the general average obtained in the experiment and the one reported for the specie. Other floral structures were not influenced by poultry litter doses. The germination times of the pollen grains did not interfere in the in vitro germination rate. The highest in vitro germination rate averages were obtained in media containing, in addition to sucrose and agar, boric acid and calcium nitrate. The different combinations of poultry litter doses did not influence the in vitro germination rates of $T$. majus pollen grains.

\section{References}

Ávila, V. S., Abreu, V. M. N., Figueiredo, E. A. P., Oliveira, U., \& Brum, P. A. (2007). Agronomic value of poultry litter after reuse for several consecutive lots. Concórdia, Santa Catarina, Brazil: Embrapa Suínos e Aves. Retrieved from http://www.cnpsa.embrapa.br/sgc/sgc_publicacoes/publicacao_x8q71d1v.pdf

Botrel, N., Madeira, N. R., \& Ribeiro, R. L. V. (2016). Edible flower, Tropaeolum majus L., a source of carotenoid. Notebooks of Agroecology Online, 10.

Cardoso, G. L., \& Lomônaco, C. (2003). Phenotypic variations and plastic potential of Eugenia calycina Cambess. (Myrtaceae) in a closed-path transition area. Brazilian Journal of Botany, 26, 131-140. https://doi.org/10.1590/S0100-84042003000100014

Chagas, E. A., Pio, R., Chagas, P. C., Pasqual, M., \& Neto, J. E. B. (2010). Composition of the culture medium and environmental conditions for germination of pear pollen grains. Rural Science, 40, 261-266.

Clark, Jr. (2008). Primocane-fruiting blackberry breeding. Hort Science Online. https://doi.org/10.21273/ HORTSCI.43.6.1637

Danner, M. A., Citadin, I., Sasso, S. A. Z., Sachet, M. R., \& Malagi, G. (2011). Mode of reproduction and viability of three species of jabuticabeira pollen. Brazilian Journal of Fruticulture, 33, 345-352.

Ferro, D. (2006). Phytotherapy: Clinical concepts (p. 502). São Paulo, Brazil: Atheneu. https://doi.org/ $10.1002 /$ ptr.1944

Figueiredo, M. A., Pio, R., Silva, T. C., \& Silva, K. N. (2013). Floral and carpometric characteristics and in vitro germination of pollen grains of mulberry cultivars. Brazilian Agricultural Research, 48, 731-740. 
Finatto, J., Altmayer, T., \& Martini, M. C. (2013). The importance of using organic fertilizer in agriculture. Academic Highlights, 5, 85-93.

Franzon, R. C., Raseira, M., \& Do C. B. (2006). In vitro germination and storage of Eugenia involucrata pollen (Myrtaceae). Brazilian Journal of Fruticulture, 28, 18-20.

Gwata, E. T., Wofford, D. S., Pfahler, P. L., \& Boote, K. J. (2003). Pollen morphology and in vitro germination characteristics of nodulating and non-nodulating soybean (Glycine max L.) genotypes. Theoretical and Applied Genetics, 106(5), 837-9. https://doi.org/10.1007/s00122-002-1097-8

Husti, A., Cantor, M., Buta, E., \& Hort, D. (2013). Current trends of using ornamental plants in culinary arts. Pro-Environment Online. Retrieved from http://journals.usamvcluj.ro/index.php/promediu/article/ download/9108/7758.19

Lemes, M. S., Maia, E., Ferreira, E., \& Stachiw, R. (2014). Use of poultry litter as fertilizer in agriculture. Brazilian Journal of Sciences of the Amazon, 3(1).

Majetic, C. J., Fetters, A. M., Beck, O. M., Stachnik, E. F., \& Beam, K. M. M. (2017). Petunia floral trait plasticity in response to soil nitrogen content and subsequent impacts on insect visitation. Flora, 232, 183-193. https://doi.org/10.1016/j.flora.2016.08.002

Noce, M. A., Oliveira, A. C., Carvalho, D. de O., \& Chaves, F. F. (2014). Fertilization of Corn Silage Used Poultry Litter in Different Doses and Application Systems. Brazilian Journal of Corn and Sorghum, 13(2), 232-239.

Nogueira, P. V., Silva, D. F. da, Pio, R., Silva, P. A. de O., Bisi, R. B., \& Balbi, R. V. (2015). Germination of pollen and application of boric acid in floral flower buds of nespereiras. Bragantia, 74, 9-15. https://doi.org/10.1590/1678-4499.0264

Pfahler, P. L. (1968). In vitro germination and pollen tube growth of maize (Zea mays L.) pollen. II. Pollen source, calcium and boron interations. Canadian Journal of Botany, 46, 235-240. https://doi.org/10.1139/ b68-039

Pigliucci, M. (2001). Phenotypic Plasticity: Beyond Nature and Nurture (p. 328). Baltimore: The Johns Hopkins University Press.

Pintão, A. M. (1995). In vitro and in vivo antitumor activity of benzyl isothiocyanate: A natural product from Tropaeolum majus. Medicinal plants, 61, 233-236.

Sangalli, A., Vieira, M. do C., \& Zarate, N. A. H. (2004). Organic wastes and nitrogen in the biomass production of Tropaeolum majus L. Science and Agrotechnology, 28(4), 831-839.

Silva, M. E. P. F., Mussury, R. M., Vieira, M. do C., Junior, V. V. A., Pereira, Z. V., Scalon, S. P. Q. (2011). Floral biology of Tropaeolum majus L. (Tropaeolaceae) and its relation with Astylus variegatus activity (Germar 1824) (Coleoptera: Melyridae). Brazilian Academy of Sciences, 83, 1251-1258. https://doi.org/10.1590/ S0001-37652011005000046

Silva, D. F. da, Pio, R., Nogueira, P. V., Silva, P. A. de O., Figueiredo, A. L. (2017). Pollen viability and quantification of pollen grains in species of fisális. Agronomic Science, 48, 365-373.

Soares, T. L., Souza, E. H. de, Costa, M. A. P. de C., Silva, S. de O., \& Santos-Serejo, J. A. dos. (2016). Viability of pollen grains of tetraploid banana. Bragantia, 75, 145-151. https://doi.org/10.1590/1678-4499.328

Sultan, S. E. (2000). Phenotypic plasticity for plant development, function and life history. Trends in plant Science, 12, 537-542. https://doi.org/10.1016/S1360-1385(00)01797-0

Stanley, R. G., \& Linskens, H. F. (1975). Pollen-biology, biochemistry and management (p. 307). Springer-Verlag, Berlin.

Vieira, M. F., \& Fonseca, R. S. (2014). Reproductive biology in angiosperms: Floral syndromes, pollinations and sexual reproductive systems (p. 24). Publishing company: UFV, Viçosa, Minas Gerais, Brazil.

Zambon, C. R., Silva, L. F. de O. da, Pio, R., Figueiredo, M. A. de, \& Silva, K. N. (2014). Establishment of culture medium and quantification of the germination of pollen grains of quince cultivars. Brazilian Journal of Fruticulture, 36, 400-407. 


\section{Copyrights}

Copyright for this article is retained by the author(s), with first publication rights granted to the journal.

This is an open-access article distributed under the terms and conditions of the Creative Commons Attribution license (http://creativecommons.org/licenses/by/4.0/). 